\title{
HANS KELSEN NA PRAHU 21. STOLETÍ
}

\author{
HERBERT SCHAMBECK
}

\begin{abstract}
Hans Kelsen at the beginning of the 21st Century
Hans Kelsen (1881-1972) led a long and diverse life - he was born into the multinational Austrian empire, experienced several political regimes, both democracy and totalitarianism, and he lectured on several universities in Europe (on the German University of Prague, among others) and in the USA. In a way, Kelsen's body of work reflects his life, it is just as rich, reaching from the theory of law to the constitutional and international law. In the legal theory, Kelsen hoped to create 'pure' - objective, exact and value-neutral - theory of law, unburdened by psychology, sociology or political theory. The aim of the legal theory should be to describe and analyse applicable law, not to concern itself with law as it should be - the latter should be left to 'legal politics' and has no place in the pure theory. Kelsen's hierarchical theory of norms (originally created by his pupil Merkl), which states that all national legal rules are part of one hierarchical structure, with higher norms having derogatory power over lower norms and the constitutional law on the top of the structure governing the procedure for the creation of all positive law within the state. As for international law, Kelsen promoted the existence of international courts as bodies to maintain international peace. These ideas, as well as his other theories, shows that Kelsen was truly 'a man standing outside one specific era', whose work is relevant to this date.
\end{abstract}

Keywords: Hans Kelsen, theory of law, hierarchical theory of norms, derogatory power, international courts, constitutional law, European law

Klíčová slova: Hans Kelsen, teorie práva, stupňovitá teorie norem, dvojjazyčná síla, mezinárodní soudy, ústavní právo, evropské právo

DOI: $10.14712 / 23366478.2017 .28$

Osobnosti jsou průvodci času a tvoří epochy, pro jejichž pochopení je nutná diskuse. Takovou osobností stojící mimo rámec jedné konkrétní epochy byl bezesporu Hans Kelsen.

\section{I. ŽIVOT HANSE KELSENA}

Vzpomenout na Hanse Kelsena zde v Praze a zabývat se tu jeho učením je s ohledem na jeho životní pout', k jejímuž výzkumu velmi přispěl Dr. Peter Kreuz, po zásluze velmi pozoruhodné! V Praze se Kelsen v roce 1881 narodil jako syn Adolfa Kelsena a jeho ženy Auguste; zatímco jeho otec zemřel již v roce 1907, jeho matku čekal delší a také osudovější život trvající bezmála 90 let. Vzpomenout na něj i na ni bylo pro mne důvodem, abych přicestoval již v roce 2013, kdy jsme si připomínali 40 . výročí úmrtí Hanse Kelsena, sem do Prahy. Zde jsem bohužel musel konstatovat, že na jeho 
rodném domě nevisí žádná pamětní deska, která by na tak významný fakt upozorňovala, pročež jsem se za významné a chvályhodné pomoci velvyslance Rakouska pana Dr. Ferdinanda Trauttmannsdorffa přičinil o její umístění.

Vyhotovení této pamětní desky umožnila v roce 2013 finanční podpora honorárního konzula pana Mag. Petera Königa, pamětní deska však byla překvapivě odcizena a její náhradu se podařilo získat díky rakouskému ministru spravedlnosti Univ.-Prof. Dr. Wolfgangu Brandstetterovi.

Hans Kelsen zemřel v roce 1973 ve vysokém věku 92 let v Berkeley, jen několik měsíců po své manželce Margarete, rozené Bondi; oba následovali př́klad svých bývalých vídeňských kolegů Alberta Ehrenzweiga a jeho manželky a nechali se zpopelnit a svůj popel rozptýlit do Pacifiku.

Nevěděli, že jsme s bývalým rakouským ministrem spravedlnosti Dr. Christianem Brodou, který se s Kelsenem přátelil už v jeho mládí, projednávali možnost jejich pohřbu do čestných hrobů na vídeňském centrálním hřbitově a plánovali jsme společně tuto poctu také pro oba spolutvưrce vídeňské právně-teoretické školy, Adolfa Merkla a Alfreda Verdrosse; nakonec však bylo možné na čestné místo posledního odpočinku ve Vídni uložit jen Adolfa Merkla v roce 1970 a jeho ženu Dr. Edith Merkl v roce 1984. V prŕípadě Verdrosse to možné nebylo, v roce 1980 byl po delším pobytu v nemocnici v Innsbrucku v souladu se svým dř́ve vyjádřeným přáním pohřben u svých rodičů tamtéž; ti, jichž se tento záměr týkal, o něm neměli samozřejmě ponětí.

Jakkoliv zůstal Kelsen se svým učením v právním myšlení 20. a 21. století stále př́tomen, nestalo se tak bohužel s místem jeho posledního odpočinku.

Tragické aspekty provázely i návrat jeho matky domů, když s dcerou Gabriele a jejím manželem utekla před nacistickým režimem do slovinského Bledu, kde v roce 1950 ve vysokém věku zemřela a byla pohřbena anonymně do hromadného hrobu, který nenesl její jméno, ale byl označen jen Davidovou hvězdou. Zemřelí nežidovského původu byli později do tohoto hrobu pohřbíváni s uvedením jména.

Na mou žádost tehdejší rakouský velvyslanec ve Slovinsku Dr. Erwin Kubesch a starosta Bledu prof. Janez Fajfar tento hromadný hrob, do něhož byla paní Auguste Kelsen pohřbena, v roce 2009 objevili. Poté, co jsem osobně toto místo posledního odpočinku navštívil, inicioval jsem zřízení pomníku s uvedením jména paní Kelsen i jejího syna Hanse a také jsem jeho zřízení finančně podpořil.

Když se paní Kelsen v Bledu ptali, zda je pravda, že jedním z jejích čtyř dětí je syn, který je právníkem, odpovídala, že ano, a říkala: Je prý významný!

Tento Kelsenův význam vychází z jeho více než devět desítek let dlouhého života, v němž měl možnost zažít v Rakousku různé státní formy, pluralitu národů, světonázorů a ideologií $\mathrm{v}$ politice, $\mathrm{v}$ mezních situacích svého života pak změny svého působiště na katedrách v Evropě i mimo ni a v neposlední řadě také dvě světové války.

V této proměnlivé době vytvořil Hans Kelsen se svými zkušenostmi ze života, který začal v končícím 19. století a trval více než sedm desetiletí ve století 20., svou právní nauku, která vycházela z řádu jediného státu někdejší habsburské monarchie, kde součástí státu, který se nazýval „Království a země na říšské radě zastoupené“, byly Čechy a Morava, a která sahala až k celosvětově organizovanému společenství států ve formě Organizace spojených národů; práce, které sahaly od spolkového ústavního zákona 
nově vzniklé Rakouské republiky z roku 1920, u níž byl významným tvůrcem, až k jeho komentáři k Chartě OSN v roce 1950. Když jsem v roce 1979 navštívil Nové Dillí, řekl mi zástupce indického parlamentu, že Rakousko je pro něj spojeno s Hansem Kelsenem, protože při své účasti na Valném shromáždění OSN vždy používá jeho komentár.

\section{PRÁVNÍ NAUKA HANSE KELSENA}

Právní nauku vypracovával Hans Kelsen kontinuálně, jednak vycházeje z plurality veřejného života rakouské habsburské monarchie, přes státní právo k mezinárodnímu právu veřejnému a jednak se svou ryzí naukou právní jako teorií pozitivního práva.

Mohlo by se zdát, že výraz „teorie pozitivního práva“ nedefinuje explicitně výlučnost a jedinečnost jediné teorie, tedy že by zdánlivě mohl považovat za možnou i existenci jiných teorií; v jejím vztahu k „pozitivnímu právu“ chce Kelsen zřetelně vyloučit jakýkoliv vztah k právu přirozenému. Jeho snahou bylo, jak konstatuje v 1. vydání „Ryzí nauky právní“, „,vytvořit čistou, tedy od veškeré politické ideologie a všech prvků př́rodních věd očištěnou právní teorii - vědom si její osobitosti plynoucí z autonomie jejího předmětu rozvíjet tendence zaměřené výhradně na poznání práva a jejich výsledky co možná nejvíce přiblížit ideálu všech věd, objektivity a exaktnosti.“ Kritizuje, že tomu v př́ípadě tradiční právní nauky tak není: „Zcela nekriticky se jurisprudence smísila s psychologií a sociologií, s etikou a politickou teorií.“ Kelsen chce svou ryzí naukou právní ze státního zř́zení eliminovat všechno, co nelze zahrnout pod pozitivní právo. Kelsena pro jeho právní teorii zajímá jen platné právo, tj. právo, které je platné a ne takové, jaké by mohlo být; posledně jmenované patř́ k právní politice a on jej od ryzí nauky právní odděluje.

Kelsen vychází v této své právně pozitivistické a hodnotově neutrální právní nauce z oddělení toho, co je (Sein), a toho, co má být (Sollen), a z fiktivního obsahu prosté základní normy, která konstituuje určitý rád právních norem, které slouží stejně jako stupňovitá výstavba právního řádu a stejně jako hierarchické uspořádání pozitivně-právní stupňovité výstavby k ústavní konkretizaci.

Tuto nauku o stupňovitém uspořádání právního řádu uvádí Kelsen poprvé v 1. vydání své knihy „Ryzí nauka právní“, která vyšla v roce 1934 ve Vídni, ta však nepochází originálně od něj, ale od jeho žáka, mého učitele Adolfa Merkla, který tuto nauku o stupňovitém uspořádání právního řádu vyvinul už o mnoho let dříve. Merkl ji uvedl již ve svých pojednáních v roce 1917 „Das doppelte Rechtsantlitz“ a v roce 1918 „Das Recht im Lichte seiner Anwendung" a rozvedl ji podrobněji v roce 1931 ve svém př́ispěvku k prvnímu jubilejnímu sborníku pro Kelsena, v němž Merkl publikoval základní prŕspěvek o „Prolegomena einer Theorie des rechtlichen Stufenbaues“. Nadto už v roce 1927 začlenil Merkl ve svém díle „Allgemeines Verwaltungsrecht“, které se stalo klasikou, nauku o stupňovitém uspořádání právního řádu do svého právního systému. $\mathrm{Na}$ této cestě jej jeho učitel Kelsen následoval. Převzetím nauky o stupňovitém uspořádání právního řádu od Merkla Kelsen svou nauku dynamizoval a propůjčil jí tak ve vztahu k životní realitě své právní teorie obzvláštní sílu. 
Jako takové stupně ve výstavbě právního řádu lze uvést ústavní zákon, běžné zákony a nařízení, jako posloupnost všeobecně abstraktních norem, po nichž následují individuální konkrétní normy, správní akty a soudní rozsudky.

Pořadí v tomto stupňovitém uspořádání samém se určuje přesně podle jeho derogační síly. Norma s vyšším pořadím deroguje normu v nižším pořadí a v rámci téhož pořadí deroguje pozdější norma normu dřívější. Vytvoření a další rozvoj svého pozitivního práva řídí stát sám. Takové pozitivní právo může vznikat jen tehdy, pokud bude dodržena každá podmínka stanovená pro proces jeho vytvoření v ústavě samé. Tímto způsobem se dostává Kelsen ke své známé nauce o identitě státu a práva.

Se svou ryzí naukou právní umožnil Hans Kelsen anatomii pozitivního práva pro každý stát a nalezl tím i širokou odezvu, která byla patrná v publikacích a nabídkách $\mathrm{z}$ univerzit, $\mathrm{v}$ roce 1930 do Kolína nad Rýnem, po sesazení nacistickým režimem v roce 1933 do Ženevy a v roce 1935 i s doporučením prezidenta Tomáše Masaryka na Německou univerzitu v Praze.

\section{STADIA V AKADEMICKÉM ŽIVOTĚ HANSE KELSENA}

Doba strávená na Německé univerzitě v Praze nebyla pro Kelsena št’astná, protože byl jako žid napadán nacistickým studenty na svých přednáškách a čeští nacionalisté mu zase nadávali do „pangermánských agentư“, „protože se po první světové válce vyslovil pro připojení Rakouska k tehdejšímu Německu“.

Kelsenova akademická př́tomnost v Praze neměla dlouhého trvání, protože po mnichovské dohodě požádal Kelsen dopisem z 10. ř́ijna 1938 děkana Ernsta Hoyera o zproštění vyučovacích povinností. Zimní semestr 1937/38 tak byl posledním Kelsenovým semestrem v Praze, protože si pro plnění svých úkolů v Ženevě vzal volno a na podzim 1938 se Československo podrobilo mnichovskému diktátu a poměry v republice se změnily. Když v roce 1939 vypukla druhá světová válka, přestal se Kelsen se svou rodinou cítit $\mathrm{v}$ bezpečí a rozhodl se opustit Evropu a odcestovat do USA, aniž by tam měl dojednáno jakékoliv pevné zaměstnání. Ve své autobiografii k tomu uvedl následující: „Jen s těžkým srdcem jsem se svou ženou opouštěl v červnu 1940 Ženevu, kde jsem sedm let uspokojivě pracoval v ideálním prostředí, abych ve věku téměř 60 let započal svou akademickou dráhu opět od začátku, nadto v zemi, jejíž jazyk jsem jen velmi nedokonale ovládal.“ Nalodil se se svou manželkou Margarete 10. června 1940 na „S. S. Washington“ v Lisabonu a 21. června 1940 přistáli v New Yorku. V roce 1978 mi na Brazilské akademii věd v Rio de Janeiro vyprávěl poslední premiér Portugalska Salazarovy éry žijící v exilu, profesor správního práva na univerzitě Coimbra Marcello Caetano, že to byl právě on, kdo manželům Kelsenovým tuto plavbu na tehdy poslední lodi umožnil.

Po svém př́ijezdu do USA čelil Kelsen různým obtížím: jednak proto, že pro něj „nebylo snadné“ se přeorientovat na angličtinu, protože anglicky sice „uměl číst, ale stěží mluvit a psát"; a jednak proto, že pro něj bylo obtížné nalézt trvalé zaměstnání. Skromnou akademickou pozici získal v akademickém roce 1940/41 svým jmenováním Oliver Wendell Holms-Lecturer na Harvard Law School, na jejíž univerzitě 18. záŕí 
1936 získal čestný doktorát; ani tak mu však smlouvu na Harvardu neprodloužili. Později mu bylo v roce 1942 zprostředkováno místo Roscoe Pound Lecturer in political science na College Berkeley Univerzity v Kalifornii.

Jak Kelsen zdůraznil ve své autobiografii, působil v Berkeley na katedře politických věd a ne na Law School a sám si k tomu poznamenal: „Se svou ryzí naukou právní bych se sice lépe hodil na právnickou fakultu. Ale americké Law Schools nemají žádný zvláštní zájem na vědecké teorii práva.“

Když se v roce 1945 sešli politici, diplomaté a právníci v San Franciscu, aby založili OSN, a pídili se po Kelsenovi, všimla si univerzita jeho významu a jmenovala ho ještě jako čtyřiašedesátiletého $\mathrm{v}$ roce 1945 plnohodnotným profesorem; $\mathrm{v}$ témže roce získal s manželkou americké občanství. V roce1952 odešel v Berkeley, kde trávil s manželkou podzim života, do penze.

Jak moc pro Kelsena znamenalo na sklonku života akademické uznání na jeho univerzitě, jsem pochopil, když jsem se v roce 1967 se svým kolegou z Innsbrucku a tehdejším rakouským ministrem spravedlnosti Univ.-Prof. Dr. Hansem Klecatskym a salcburským rektorem Univ.-Prof. Dr. Rene Marcicem chopil inciativy k vydání sebraných spisů vídeňské právně-teoretické školy a zaslal jsem Kelsenovi svůj návrh jeho životopisu a on mě požádal, abych v něm uvedl, že je v Berkeley na univerzitě po něm pojmenovaná knihovna. Když chtěl po jeho smrti rektor této univerzity toto pojmenování odstranit, požádala mě Kelsenova dcera paní Maria Feder, abych intervenoval u rektora v Berkeley za jeho zachování, což se mi nakonec podařilo.

Pokud budeme podle Kelsenova života posuzovat jeho vědecké literární životní dílo, vycházelo z právní filosofie, přes nauku o státu a bylo zaměřeno na ústavní právo a později čím dál více na mezinárodní právo veřejné. Chtěl využít společenství lidí, kteří akceptují platnost vnitrostátních norem a později norem mezinárodního práva k nastolení a zajištění míru.

\section{HANS KELSEN A JEHO RYZÍ NAUKA PRÁVNÍ}

Kelsen se narodil v době staré habsburské mnohonárodnostní monarchie, v níž také vyrostl a byl vychováván. V tomto multinacionálním prostředí, přetrvávajícím až do roku 1918, chtěl se svou ryzí naukou právní, která byla zaměřena jen na formu, a ne na obsah právních ustanovení, umožnit hodnotově neutrální stát, čímž by se zabránilo konfliktům. Když jsem během svého hostování v USA v roce 1967 obdržel od manželů Kelsenových na Velký pátek pozvání, zeptal jsem se Hanse Kelsena, proč nezakotvil politické strany, které se staly později tak dominantními, do rakouské spolkové ústavy. Odpověděl mi, že to „mlčky předpokládal“".

Kelsen chápal, zejména ve své v roce 1925 uveřejněné Obecné nauce o státu (Allgemeinen Staatslehre) nauku o státu jako státoprávní učení, které je pro něj naukou o objektivním právu. Tímto způsobem byl Kelsen monistou, díky svému státoprávnímu učení v nauce o státu.

Georg Jellinek, kterého Kelsen zažil v Heidelbergu během svého stipendijního pobytu, sepsal svou státovědu v roce 1900 dualisticky, a sice jako státoprávní nauku a sociál- 
ní nauku, nadto s mnoha historickými konotacemi. Po druhé světové válce šel mnichovský státovědec Hans Nawiasky ještě o krok dále a pojal v letech 1945, 1955 a 1956 svou státovědu trialisticky, sice jako státoprávní, sociální a ideovou nauku o státu.

Tato monistická a pozitivistická právní věda a státověda, s níž chtěl Kelsen čelit pluralitě ve veřejném životě své doby, byla výrazem Kelsenovy snahy o mír, která se v narůstající míře vědeckého zájmu vztahovala vedle právní filosofie a státoprávní vědy také na nauku o mezinárodním právu veřejném.

Obzvláště i později, během jeho pobytu $\mathrm{v}$ Ženevě a během všech následujících let v USA, zaměstnával Kelsena problém míru a organizace státu do společenství, jakým byla Společnost národů a OSN; pro OSN zveřejnil v roce 1950 vlastní komentáŕ k Chartě OSN a poukázal v něm na nutnost a význam mezinárodních soudních dvorů, jako jeden z prvních již v roce 1944 ve svém díle „Peace throught Law“. Kelsenovi jde také o význam soudů pro vztah práva a moci, i míru a spravedlnosti.

\section{DEMOKRACIE A RELATIVISMUS}

Se šiří své životní cesty spojil Hans Kelsen šiřii svého právního myšlení, $\mathrm{v}$ němž při veškerém oddělení práva a morálky nacházel nutnou odpovědnost $\mathrm{v}$ politice.

To ukazuje jeho později velmi často citované a také často překládané dílo „Vom Wesen und Wert der Demokratie“. Toto dílo jsem prezentoval v roce 2013 po své čestné promoci na právnické univerzitě Ukrajinské akademie věd v Kyjevě v ukrajinském překladu se svým úvodem.

V tomto díle řeší Kelsen nejdůležitější otázky demokracie, zejména s ohledem na ústavní státnost. Mnoho ze závěrů, k nimž tehdy došel, jako např́klad o parlamentarismu, politických stranách a vztahu zastupitelské a plebiscitární demokracie je aktuálních i dnes. Velmi často je odkazováno na jeden z Kelsenových výroků, a sice že „relativismus je světový názor“, „který je předpokládán demokratickou myšlenkou“. V této souvislosti odkazuje na kapitolu 18. Janova evangelia, podle které hlasování lidu dopadne proti Ježíši, a když se Pilát zeptá lidu, koho má propustit, křičí všichni Barabáš, a jak uvedl Kelsen, kronikáŕ k tomu dodal: „Byl pak ten Barabáš lotr.“

Tato „událost ze života Ježíše“ patř́ podle Kelsena „k nejúžasnějším, co světová literatura vytvořila; a aniž by to zamýšlela, roste do tragického symbolu relativismu a demokracie“.

V literatuře nezůstal Kelsen se svým odkazem na relativismus a demokracii později osamocen. Když jiný z profesorů, a sice kardinál Joseph Ratzinger, celebroval jako děkan kolegia kardinálů dne 18. dubna 2005 před katedrálou svatého Petra mši svatou „Pro eligendo Romano Pontifice“ - tehdy jsem byl na mši osobně př́tomen - řekl: „S kolika názorovými směry jsme se v posledních desetiletích seznámili, kolik ideologických proudů, kolik způsobů uvažování... Malá bárka myšlení mnoha křest’anů byla mnohokrát těmito vlnami rozkolísána, vržena od jednoho extrému ke druhému; od marxismu k liberalismu až k libertinismu; od kolektivismu k radikálnímu individualis$\mathrm{mu}$; od ateismu k vágnímu religióznímu mysticismu; od agnosticismu k synkreatismu 
a tak dále... Buduje se tak diktatura relativismu, která neuznává nic za definitivní a jejíž poslední mírou je vlastní já a vlastní chtění.“

Pokud porovnáme oba citáty, obsahují oba, třebaže jeden pochází z oblasti právní vědy a druhý z oblasti teologie, stejný výrok, a sice odkaz na relativismus ve veřejném životě. Tento relativismus ve veřejném životě, který patří k tomu, co je ve státě prepozitivní, zažil Kelsen ve svém životě v různých podobách a musel se s ním mnohokrát vyrovnat. Poznání tohoto relativismu spojil Kelsen s odpovědností ve státě, kde nést odpovědnost vyžaduje podávat odpovědi a odkazovat na význam tvorby právních předpisů ve státě.

Tato tvorba právních předpisů ve státě probíhá na základě příslušné ústavy, která v demokratickém ústavním státě vyžaduje politické rozhodování. Adolf Merkl, který byl Kelsenovým posluchačem a později i spolutvưrcem vídeňské právně-teoretické školy, označil ústavu za kodifikovanou politiku.

S ohledem na jeho ryzí nauku právní zastával Kelsen ve vztahu k tvorbě zákonů hodnotový naturalismus a názorovou indiferentnost, která je patrná i v návrhu rakouské spolkové ústavy, na nějž měl rozhodující vliv. Tuto spolkovou ústavu, na jejíž přípravě se Merkl spolupodílel, označil za ústavu právní cesty, o níž Rene Marcic konstatoval, že je pro ni charakteristické „dojednané mlčení“ o hodnotových soudech.

Toto takzvané „mlčení“ zkoncentrovalo spolkovou ústavu na úpravu státního zřízení, převzala tak katalog základních práv z prosincové ústavy 1867 rakousko-uherské monarchie a změnila její decentralizovanou jednotnou státnost na spolkový stát demokratické republiky. Pokud odhlédneme od rozdělení úkolů nutného pro spolkové rozdělení pravomocí pro účely práva a moci, kultury a obecného blaha, neobsahovala spolková ústava žádné výslovné hodnotové soudy, čímž si ustavující národní shromáždění ušetřilo střety na téma plurality regionů, světonázorů a ideologií.

Vždy, když je právně-pozitivistickým základním postojem zdrženlivost ve věci hodnotových soudů, ustanovení o cílech státu a jeho účelu v ústavním právu, zbývá odpovědnost politiky za další vývoj ústavního práva a tvorbu běžných zákonů; tímto způsobem se Rakousko stalo kulturním, hospodářským a sociálním státem na základě běžných zákonů.

V tomto vývoji vznikla vedle demokratických a justičních základních práv i základní sociální práva, která jsou uvedena v rámci Lisabonské smlouvy v Listině základních práv EU.

K těmto základním právům, která jsou zaměřena na svobodu od státu, ve státě a na svobodu garantovanou státem, přibylo v poslední době zejména s ohledem na ohrožení životního prostředí základní existenční právo na život, na které odkazuje papež František ve své encyklice Laudato si.

V př́padě vývoje základních práv a odpovědností lidí za právo ve státě je však nutné uvést, že ne všechny nároky a hodnoty, které by zasluhovaly být základními právy, musejí být také způsobilé základními právy být. Kdo by v dnešní době nepocitoval velmi často potřebu základního práva na klid a ochranu před hlukem, základního práva na bezpečnost provozu a ochranu před nezodpovědností účastníků provozu a základního práva na to, být sám, a ochranu před obtěžováním. 
Tyto dimenze toho, co je z normativně-právního hlediska možné a nemožné, ukazují odpovědnost člověka a odkazují na vztah práva a individuální a sociální morálky. Tento vztah a jeho právně-normativní vyjádření jsou patrné v ústavách jednotlivých států.

\section{NOVÉ USPOŘÁDÁNÍ INTEGRUJÍCÍ SE EVROPY}

Tyto společné ústavní tradice států tvoří základy EU, které již v roce 1993 vyžadovaly závěry Evropské rady v Kodani, a stanovovaly kromě převzetí Acquis Communautaire i hospodářská a politická kritéria pro přistoupení nových členských států k EU. K tomu přibyla podle článku 6(3) Smlouvy o EU „základní práva, která jsou zaručena Evropskou úmluvou o ochraně lidských práv a základních svobod a která vyplývají z ústavních tradic společných členským státům..., která tvoř́i obecné zásady práva Unie“.

I uspořádání integrující se Evropy vykazuje v rámci EU formu stupňovitého právního uspořádání: s primárním unijním právem, které obsahuje smlouvy o založení, obecné právní zásady a odpovědnost státu. Od Lisabonské smlouvy patř́ k primárnímu právu EU i Smlouva o Evropské unii, Smlouva o fungování EU a Listina základních práv EU. Pro výkon pravomoci Unie přijímají orgány dle čl. 288 odst. 1 Smlouvy o fungování Evropské unie nařízení, směrnice, rozhodnutí, doporučení a stanoviska; ty tvoří sekundární unijní právo. Terciárním unijním právem jsou pak abstraktní obecné právní akty vzniklé na základě zmocnění vycházejících ze sekundárního práva.

V tomto sdružení států EU čítajícím nyní 28 členských států je normativní právo tohoto společenství států konstituující; umožňuje, aby toto sdružení států EU bylo vnímáno jako hospodářské a měnové společenství a jako právní společenství, které vychází $\mathrm{z}$ určitých hodnot a může tak přispět i k míru. To po přijetí Lisabonské smlouvy předpokládá společné uvědomění na úrovni evropské, státní i vlastenecké, které pro zachování subsidiarity stanovuje podle článku 5 Smlouvy o Evropské unii a článku 69 Smlouvy o fungování EU vlastní kontrolní mechanismy.

Kelsen se sice Evropskou unií nikdy nezabýval, ale jak zjistili Jürgen Busch a Tamara Ehs, zabýval se během svého pobytu v Ženevě na Institut universitaire de hautes études internationales spolu s Paulem Guggenheimem otázkou budoucnosti Evropy.

Jak zjistili Busch a Ehs, konstatuje Kelsen v této své studii „nutnost organizační struktury, která nezř́íí mezinárodní politický orgán, ale mezinárodní soudní dvưr jako centrální orgán, aby mohla spíše garantovat mír“. EU se však vyvinula jinak; nelze ji srovnat se státem a má charakter sui generis.

Pokud se v souvislosti s EU použije pojem ústava, pak ne jako nejvyšší řád superstátu EU nad členskými zeměmi EU, ale spiše jako normativní základní řád EU jako „sdružení státư“, jak ji označil německý ústavní soud.

Původní Smlouva o ústavě EU vytvářela dojem vzniku evropského superstátu, z toho důvodu byla odmítnuta a nahrazena reformní smlouvou, která sestává ze Smlouvy o EU, Smlouvy o fungování EU a Listiny základních práv EU a je pojmenována po místě svého uzavření jako Lisabonská smlouva. 
Pokud porovnáme Kelsenovo učení ve vztahu k právu a státu s potřebami v EU, vyžadují obě odpovědné myšlení, které předchází jak legislativnímu procesu, tak výkonu práva, v němž každý může aplikovat svůj prepozitivní postoj, at’ už se jedná o náboženství, morálku, světonázor či ideologii. Jsou spoluurčujícími faktory pro aktuální politické rozhodování, které vede ke tvorbě zákonů.

\section{POROZUMĚNÍ STÁTU A PRÁVU JAKO ÚKOL}

Kelsen se svou ryzí naukou právní vyslovil pro ústavní a právní stát, který neměl obsahovat žádné prepozitivní podmíněnosti a předpisy. To odpovídalo zcela jeho hodnotové neutralitě a názorové indiferentnosti; ta byla ve 20. století zneužita autoritářskými a totalitními státy, s nimiž se střetl během svého života i sám Kelsen.

$\mathrm{V}$ této souvislosti mi jednou $\mathrm{v}$ době politického dělení Evropy řekl jeden komunistický univerzitní profesor, že Kelsenovu kritiku marxismu sice odmítá, jeho právní nauku a nauku o státu však používá; ta byla zaměřena na právní formu a ne s hodnotícím aspektem na právní obsah!

Jinak tomu bylo u Adolfa Merkla, který už ve svých prvních uveřejněných pracích, jednalo se o recenzi knihy Ericha Junga „Das Problem des natürlichen Rechts“, která vyšla v roce $1914 \mathrm{v}$ Zeitschrift für öffentliches Recht, téměř jako doznání prohlásil, že připisuje přirozenému právu poslání „,být stálým, regulativním principem pozitivního práva“. Jako doplnění a také ovlivněn svou manželkou pak Merkl v jedné ze svých posledních publikací, šlo o speciální vydání Österreichischen Zeitschrift für öffentliches Recht o „Ryzí nauce právní a morálním řádu“, věnované Hansi Kelsenovi k 80. narozeninám, konstatoval: „Ryzí nauka právní je teoretickou nezbytností a průnikem do práva právě díky svému odsouzení vměšování z jiných normativních a explikativních věd. Protože to však až př́liš osciluje mezi pokusem o spravedlnost a její karikaturou, je nutné doplnění právní teorie právní etikou.“" Merkl se tím vyslovil pro doplnění formální právní nauky o úvahy o právním obsahu; já sám jsem měl tehdy tu čest na pozvání Alfreda Verdrosse také přispět článkem do tohoto speciálního vydání, a sice o „گ̌́ádu a platnosti““.

$\mathrm{K}$ řádu ve státě nastolenému prostřednictvím práva tak Hans Kelsen se svou ryzí naukou právní poskytl trvalý př́spěvek, nebot' tato jeho ryzí nauka právní zprostředkovává platnou anatomii pozitivního práva, která vede k pochopení práva států a jejich normativních řádů.

To, pro co bude konstitucionalita a legitimita jednotlivých států použita, vyžaduje politiku pro rozhodování o legislativě. K politice stran měl sám Kelsen odstup; to se velmi silně projevilo, když ho předseda rakouské sociální demokracie Karl Seitz v roce 1930 chtěl navrhnout jako člena ústavního soudu a on to odmítl, ,protože nechtěl vykonávat soudcovský úřad jako pověřenec nějaké strany“; něco takového „považoval za zcela neslučitelné se soudcovskou nezávislostí“.

I Adolf Merkl zůstával ve svém působení nezávislý na stranické politice.

Pokud na závěr konfrontujeme Kelsenovu cestu s jeho učením, platí pro obojí slovo „postoj“; s ryzí naukou právní chtěl dát státu v době mnohých pluralit jasný směr 
a postoj a ve svém životě se svým postojem politické nezávislosti zprostředkovat lidskou důvěryhodnost; obojí zasluhuje respekt, který vzdáváme komplexnosti jeho nauky s jejími diferencovanými úvahami, i jeho životu zde na místě jeho narození touto vzpomínkovou akcí.

Prof. Dr. Dr. h.c. mult. Herbert Schambeck, emeritní prezident Spolkové rady Rakouské republiky, emeritní profesor na Univerzitě v Linci alfred.obermueller@oevpklub.at 